\title{
HOW DOES EXERCISE SUPPORT DIETARY APPROACHES TO WEIGHT LOSS AND BETTER HEALTH?
}

\author{
Katarina TOMLJENOVIĆ BORER
}

School of Kinesiology, The University of Michigan, Ann Arbor, USA

Corresponding author:

Katarina T. BORER

School of Kinesiology, The University of Michigan, 1402 Washington Heights, Ann Arbor, MI 48109-2013, USA

Tel. +1 734 249-8809

E-mail: katarina@umich.edu

\section{ABSTRACT}

The rapid global rise of obesity incurs a heavy personal and healthcare burden due to obesity-associated morbidities and shortening of life. The purpose of this review is to provide evidence-based strategies for prevention, reversal, and mitigation of obesity and its sequelae. To that end, this review highlights the features of human physiology that favor fat accretion and interfere with fat loss. Strategies for prevention of obesity include understanding the basis for the strong motivating properties of palatable food, for human inability to consciously detect calories eaten or calories expended through exercise, for metabolic and hormonal adaptations to negative energy balance that drive weight regain, and for evolutionary natural selection which likely led to high human capacity for fat storage. Reversal of obesity is difficult primarily due to metabolic, hormonal, and behavioral reactions to body fat loss. Reduced resting metabolic rate presents a physiological challenge whether the weight loss is achieved through dietary restriction or energy expenditure of exercise. Increased insulin sensitivity after body fat loss drives resynthesis of storage substrates including triglycerides in the adipose tissue, muscle glycogen, and proteins, thus contributing to weight regain. Reduced basal plasma leptin concentration elicits a strong hunger drive. Mitigation of obesity-associated morbidities involves adding exercise energy expenditure to deliberate control of the quantity of food eaten, reducing postprandial hyperinsulinemia by lowering the carbohydrate load of the diet, and exercising after, rather than before, the meals to facilitate improved glucose tolerance.

Keywords: obesity morbidities exercise insulin leptin body weight 


\section{KAKO GIBALNA VADBA DELUJE KOT PODPORA DIETI PRI ZNIŽEVANJU TELESNE MASE IN IZBOLJŠEVANJU ZDRAVJA?}

\section{IZVLE $\check{C} E K$}

Hiter globalni razmah debelosti in prekomerne telesne mase zaradi številnih z njim povezanih bolezni in posledično krajšanja življenjske dobe, predstavlja vedno večje breme tako za posameznike kot tudi za zdravstvene sisteme. Namen preglednega članka je predstaviti na dokazih temelječe strategije za preprečevanje in ublažitev posledic prekomerne telesne mase. Izpostavili bomo fiziološka ozadja, ki imajo odločilno vlogo pri kopičenju maščobnega tkiva, ter tista, ki preprečujejo izgubo maščobe. Strategije za preprečevanje prekomerne telesne mase vključujejo tako razumevanje osnovnih vzvodov, ki vodijo do močne navezanosti človeka na okusno hrano, kot tudi razumevanje osnov človekove nezmožnosti, da bi zavestno prepoznal količino kalorij, ki jih je prejel z zaužito hrano ali tistih, ki jih je s telesno aktivnostjo porabil. Izpostavili bomo presnovne in hormonalne adaptacije na negativno energijsko bilanco, ki vodijo v pridobivanje telesne mase in evolucijsko naravno selekcijo, ki je verjetno vodila do visoke sposobnosti človeka, da v telesu kopiči zaloge maščobe. Spreminjanje trenda naraščanja prekomerne telesne mase je težavno predvsem zaradi presnovnih, hormonalnih in vedenjskih odzivov na izgubo telesnih maščob. Pri zmanjšani stopnji presnove v mirovanju predstavlja poseben fiziološki izziv vprašanje ali gre $v$ teh primerih za zmanjšanje telesne mase zaradi restriktivne prehrane ali zaradi povečanja porabe energije, kot posledico gibalne aktivnosti. Povišana stopnja inzulinske rezistence po izgubi telesnih maščob vodi $v$ resintezo skladiščenih substratov, vključno trigliceridov v maščobnem tkivu, mišični glikogen in proteine, kar prispeva k ponovnemu pridobivanju telesne mase. Zmanjšane koncentracije bazalnega leptina v plazmi sprožijo občutek lakote. Zmanjšanje posledic s prekomerno telesno maso povezanih bolezni, ob zavestnem nadzorovanju količine zaužite hrane, vključuje tudi dodatno porabo energije s pomočjo gibalne vadbe, zniževanje postprandialne hiperinzulinemije z nižanjem količine ogljikovih hidratov $v$ prehrani ter z izvajanjem gibalne/športne aktivnosti po zaužitem obroku, raje kot pred njim, saj to izboljšuje toleranco za glukozo.

Ključne besede: debelost, slabotnost, gibalna vadba, inzulin, leptin, telesna masa 


\section{INTRODUCTION}

Obesity has risen rapidly over the past half a century in all of 200 sample countries of the world (NCD Risk Factor Collaboration, 2017). It increased from 3.2\% in men and $6.4 \%$ in women in 1975 to $10.8 \%$ and $14.9 \%$, respectively, in 2014 . In $2014,2.3 \%$ of world's men and 5\% of women were severely obese, and $0.64 \%$ men and $1.6 \%$ women were morbidly obese. By 2025 , global obesity is projected to reach $18 \%$ in men and $21 \%$ in women, and 6 and $9 \%$ are, respectively, likely to become severely obese. In the US, 32.2\% of men and $35.5 \%$ of women were obese in 2016 (Hales, Carrol, Fryar \& Ogden, 2017). Their health care burdened the economy with 147 billion USD (Finkelstein, Trogdon, Cohen \& Dietz, 2009). The corresponding health care costs of obesity in Europe in 2008 were 10.4 billion euros (Muller-Riemenschneider, Reinhold, Berghofer, \& Willich, 2008).

Obesity-associated morbidities include hypertension (Vaněčková et al., 2014), atherosclerosis (Lovren, Teoh, \& Verma, 2015), hypercoagulability of blood (Samad \& Ruf, 2013), endothelial dysfunction (Iantorno et al., 2014), coronary vascular (Rankinen, Sarzynski, Ghosh, \& Bouchard, 2015), kidney (Ritz, Rychlik, Locatelli, \& Halimi, 1999), and heart disease (Després et al., 1996), stroke (Field et al., 2001), and particularly type 2 diabetes (T2D). These obesity-linked morbidities increase the risk of mortality by two to three fold (Adams et al., 2006). The close association between obesity, peripheral tissue resistance to insulin action, and T2D is reflected in the frequently used descriptive term "diabesity" (Farag \& Gaballa, 2011).

Since the driver of recent rapid increases in obesity is the interaction between behavioral choices and human physiological barriers, the purpose of this review is to describe behavioral strategies that could prevent or reduce obesity and mitigate its associated morbidities.

\section{METHODS}

The data for this review are based, in part, on PubMed search for the scientific reports on the behavioral and physiological controls of food intake and on the physiological, psychological, and hormonal barriers to weight loss, as well as, in part, on the author's research findings and views on the regulation of energy balance in humans (Borer, 2005; 2008; 2010; 2014; 2019; Borer, Wuorinen, Chao, \& Burant, 2005; Borer, Wuorinen, Ku \& Burant, 2009; Wuorinen \& Borer, 2013; and Lin \& Borer, 2016).

Five points will be interpreted from the evidence-based research:

(1) The endocrine basis of obesity-associated morbidities; (2) Physiological features that facilitate overeating, (3) Evolutionary burden of high human capacity for obesity, (4) Failure of spontaneous physical activity to compensate for obesity; and (5) Dietary and exercise solutions to some obesity-associated morbidities. Integration of these points will guide the recommendation for behavioral strategies toward prevention, reversal, or mitigation of obesity and its associated morbidities. 


\section{RESULTS}

\section{The endocrine basis of obesity-associated morbidities}

Obesity leads to a disturbance in the endocrine regulation of body energy storage and its mobilization by reducing the effectiveness of its chief endocrine agent insulin. Circulating glucose and amino acids elicit insulin secretion, and activate its four chief actions, to increase uptake of these nutrients by muscle and other energy-depleted tissues, to reduce the concentration of circulating glucose by increasing its metabolism, to further reduce circulating nutrients by promoting their storage in the form of muscle and liver glycogen, adipocyte triglyceride, and tissue protein, and finally, to block the breakdown, release, and metabolism of metabolic fuels from their inert storage form. It is less well-recognized that a second hormone, leptin, also plays a key role in the mealassociated regulation of energy balance. While its release from the white adipose tissue (WAT) is universally recognized, it is less well known that leptin gets also released from the stomach during meal eating (Sobhani et al., 2000). Its secretion and actions are linked to that of insulin in a counter-regulatory fashion. Insulin stimulates leptin release during meal-eating, and leptin then restrains all four of the insulin's actions as well as insulin release. It indirectly counter-regulates the energy storage actions of insulin by promoting lipolysis and stimulation of lipid metabolism (Borer, 2014). This endocrine counter-regulation of short-term energy balance is disrupted in obesity by the resistance of peripheral tissues to the actions of both insulin and leptin.

Increased insulin and leptin resistance in obesity (Samuel, Petersen, \& Shulman, 2010; Shulman, 2014a) is reflected in the proportional rise in fasted, basal and stimulated concentration of both hormones as a function of increased body fat (Figure 1). The effect of obesity on the basal insulin concentration is expressed in a disposition index (DI) (Lorenzo et al., 2010). DI is a product of insulin sensitivity and the amount of insulin secreted in response to blood glucose level. Plotted as insulin response as a function of insulin sensitivity, the parabolic curve shows that little insulin is needed to stimulate the glucose uptake when insulin sensitivity is high, but a high insulin concentration is required when the peripheral tissues are insulin-resistant and when insulin sensitivity is low. Insulin-resistant peripheral tissues in obesity thus require high basal and stimulated insulin concentrations.

The rise in the basal or fasted concentrations of insulin and leptin are a consequence of a fundamental relationship between prevailing hormone concentration and the number of specific hormone receptors on the cell membrane. The number of receptors on energy-storing cells (like WAT, liver, or muscle) varies with the state of energy depletion or repletion. Energy depleted adipocytes are smaller and have a higher density of insulin receptors on their membranes than lipid-packed adipocytes in over-fed or obese state (Olefsky \& Reaven, 1975). This relationship is explained in Figure 2 (Mendelson, 1996). In this hypothetical example, a biological response is possible when insulin binds to 5000 receptors. Any time the cell has in excess of 5000 insulin receptors (called "spare receptors"), the cell sensitivity to insulin, and the affinity of the hormone 

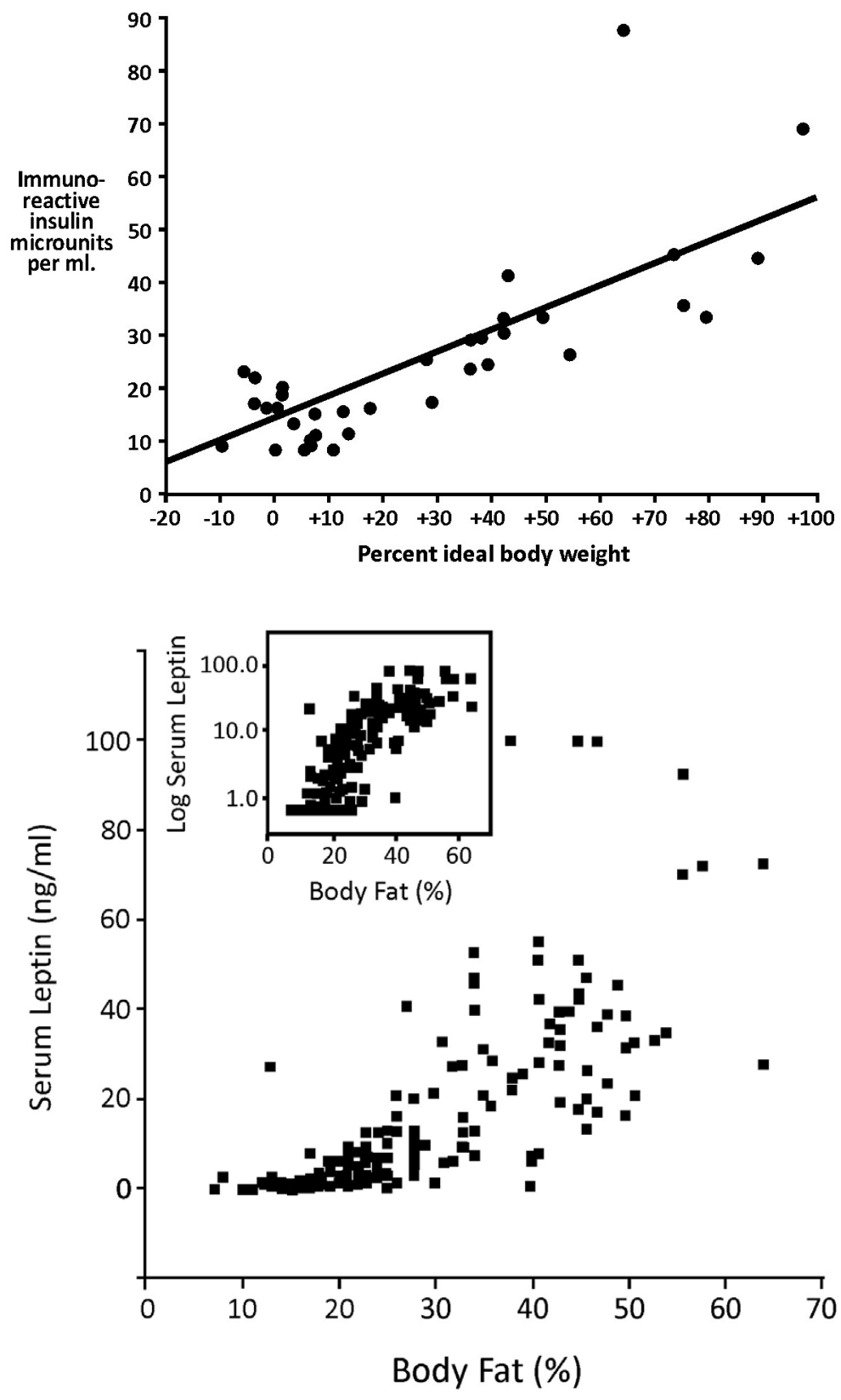

Figure 1. The positive correlation between fasting serum insulin (top) and fasting serum leptin (bottom) as a function of percentage body weight or body fat. Data for insulin from Bagdade, 1968 and for leptin from Considine et al., 1996. 

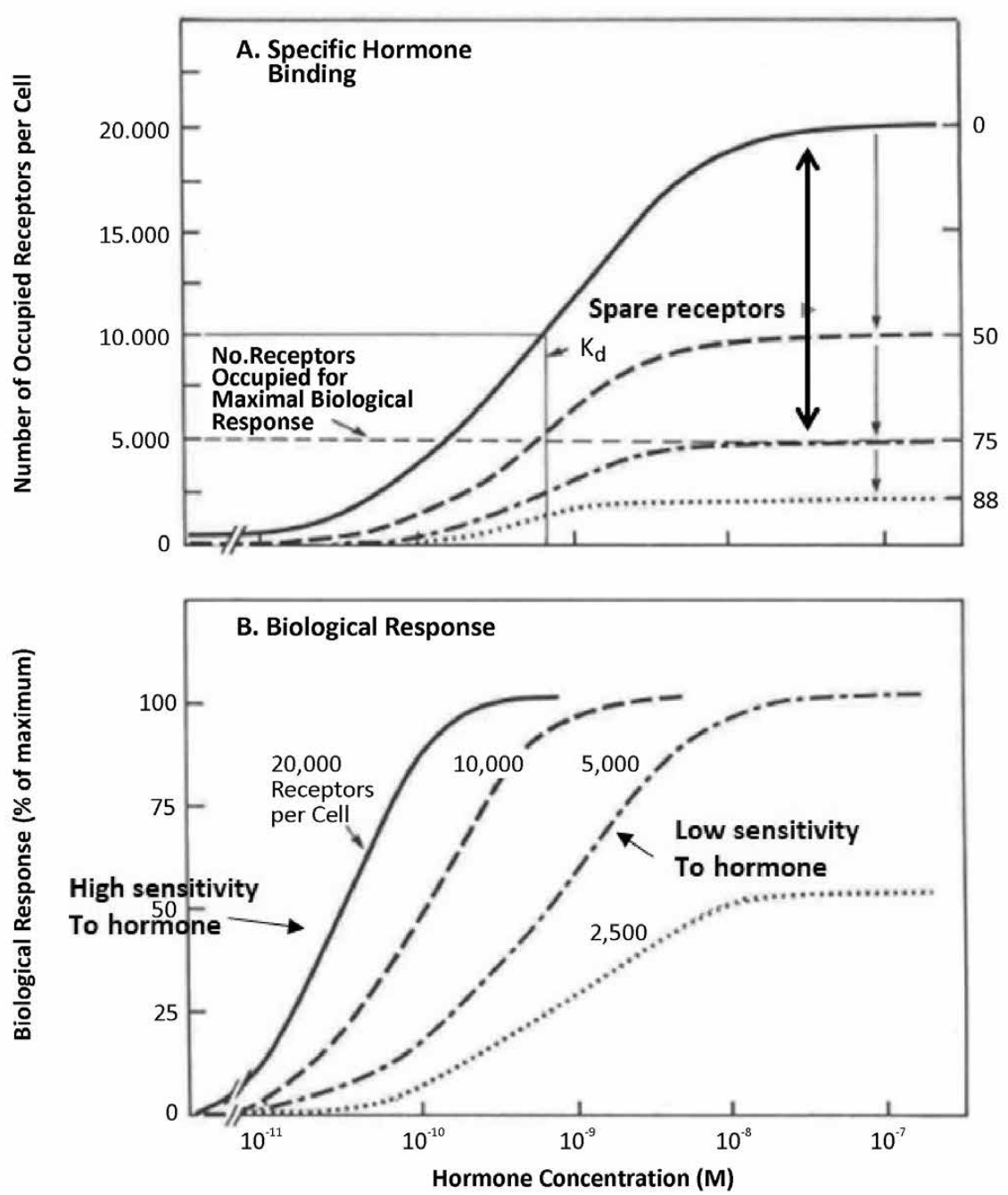

Figure 2. The sensitivity of peripheral tissues to fasting concentration of a hormone declines in parallel with the number of receptors on the target cell surface and the repletion of target cells with storage fuels. As the amount of storage fuel and the cell size increase, the number of receptors on the surface membrane declines. At the same $\mathrm{Km}(A)$, tissue sensitivity to a hormone increases in proportion to the number of "spare receptors above the threshold number required to elicit a biological response (5000 receptors in this example). With the smaller number of receptors in energy-replete cells, resistance to a hormone manifests in the form of a higher hormone concentration required to elicit the biological response (B). From Mendelson, 1996. 
for the cell are increased, and the biological effect is achieved with lower insulin concentration (Figure 2A). The figure also shows the way to express hormone-receptor affinity or hormone sensitivity as half-maximal concentration of the hormone producing the biological effect (Kd or dissociation constant). When the cell is more energy replete and has fewer (about 5,000 to 10,000) membrane receptors, hormone concentration required to produce full (100\%) biological response will have to be higher (Figure $2 \mathrm{~B}$ ).

This fundamental rule of hormone interaction with the number of its receptors in the context of cellular energy depletion or repletion explains why obese tissues become more resistant to insulin and why the basal concentration of insulin and leptin rise with obesity. So, postprandial hyperglycemia and hyperinsulinemia are the consequence, respectively, of reduced effectiveness of insulin to stimulate glucose uptake by peripheral tissues and to inhibit glucose mobilization from the liver and free fatty acid mobilization from WAT because of insulin resistance. Hyperglycemia and compensatory hyperinsulinemia (Taylor, 2013) lead to glycation of circulating proteins and the formation of advanced glycation products associated with pathological oxidative stress (Nowotny, Jung, Höhn, Weber \& Grune, 2015). High fasting concentrations of FFAs resulting from diminished insulin suppression of their mobilization from storage fat (Yazıc1 \& Sezer, 2017) directly interfere with insulin signaling in the muscle (Schenk \& Horowitz, 2007).

Obesity-associated pathologies also result from excess fat deposition in ectopic sites when the capacity of adipocytes to hypertrophy exceeds the capacity of fat storage in the WAT. Excess fat storage in the liver (van der Zijl et al., 2011; Taira et al., 2013; Shulman, 2014b), the pancreas (van der Zijl et al., 2011), the muscle (Taira et al., 2013), and the kidney (Guebre-Egziabher et al., 2013) cause lipotoxicity in addition to insulin resistance. Non-alcoholic fatty liver disease (Than \& Newsome, 2015) and steatohepatitis (Neuman et al., 2014) result from lipotoxic fat accumulation in the liver. Obesity drives the progression from insulin resistance, reduced glucose tolerance, and pre-diabetes to T2D. The incidence of T2D has increased from 4.4 million or $2.4 \%$ of US population in 1970 s (Fox et al. 2006) to 29.1 million or $9.3 \%$ of the population in 2014 (National Diabetes Statistics Report, 2017). Globally, in 2010, there were 284 million diabetics representing $6.4 \%$ of the world population. If the increases continue, there will be 490 billion of diabetics in 2030 (Farag \& Gaballa, 2011).

\section{Physiological features that facilitate overeating}

Overwhelming evidence indicates that excessive food intake, rather than insufficient physical activity, is the primary cause of weight gain and obesity. Why is this behavior not subject to negative feedback to counteract the excessive energy gain? This question is often either overlooked or incorrectly attributed. The incorrect attribution is due to the hypothesis which posits that changes in the quantity of body fat control hunger, meal eating, and motivation for physical activity in a way that maintains healthy 
Katarina TOMLJENOVIĆ BORER: HOW DOES EXERCISE SUPPORT DIETARY APPROACHES TO WEIGHT LOSS ..., 31-58
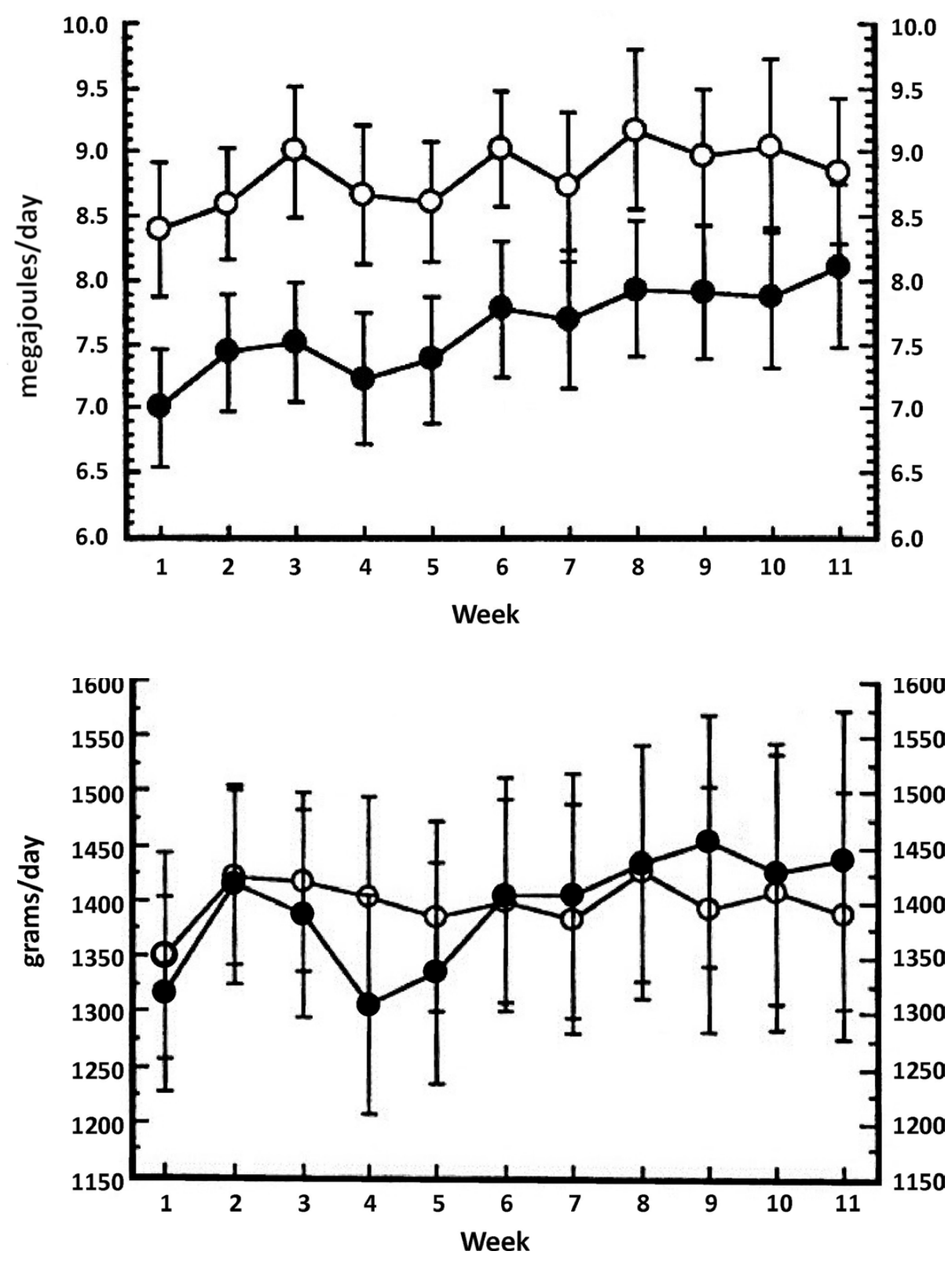

Figure 3. Energy content of diets (35-30\% fat open circles, 20-25\% fat solid circles) did not affect the amount of food eaten over 11 weeks (top). Instead, a similar volume of food was eaten over 11 weeks unaffected by dietary energy density (bottom). From Kendall, Levitsky, Strupp, \& Lissner, 1991. 
body fat content (Schwartz, Woods, Porte, Seeley, \& Baskin, 2000). This hypothesis is not supported by facts. The simple and convincing answer to the feedback question is that humans (and probably most animals) cannot directly detect calories eaten in meals or calories expended in physical activity. This flaw in our physiological design, compounded by the strong motivating properties of palatable food, allow environmental influences such as portion size, easy availability of meals, and social facilitation, to drive food overconsumption. How good is the evidence that humans cannot track mealassociated intake of calories and exercise-associated expenditure of calories? That the volume of food eaten rather than the nutrient energy is the critical determinant of nutrient intake was demonstrated almost 30 years ago (Kendall, Levitsky, Strupp, \& Lissner, 1991). Lower energy low-fat (20-25\% fat) or higher energy high-fat diets (35-40\% fat diet) were available for 11 weeks. The volunteers spontaneously ate a constant volume of food per day regardless of the $1.1 \mathrm{KJ}$ daily energy difference in the two diets (Figure 3) and ended up with a different weight change.

A more relevant demonstration of human inability to track calories eaten in a meal or expended in exercise was done 18 years later in a study demonstrating that only a variable quantity of food taken by mouth and processed by gastrointestinal tract affected the sensation of hunger and fullness, while intravenous infusion of nutrients and substantial pre-meal exercise expenditure had no such effect (Borer, Wuorinen, $\mathrm{Ku}, \&$ Burant, 2009, Figure 4).

Furthermore, changes in plasma concentrations of both insulin and leptin correctly tracked calories gained or lost, but exerted no influence on the perception of hunger or satiation in contradiction to the homeostatic hypothesis of Schwartz et al. (2000). (Figure 5).

These data show that our perception of satiation is based on gastrointestinal fullness, a signal that can easily be overlooked, and that insulin and leptin, postulated to affect appetite in response to changes in the size of WAT (Schwartz et al., 2000), do not operate during regular meal-to meal eating as such meal-associated changes in body fat are exceedingly small.

The second flaw in our physiological design is that food provides a powerful positive motivation to eat whether or not we are experiencing energy deprivation (Berridge, 2009). Food activates the same brain centers of reward as the various pleasurable events like sex, stimulating drugs, and direct electrical or pharmacological stimulation by neurotransmitters such as dopamine (Berridge, 2009), morphine-like endogenous opiates, and endocannabinoids (Kirkham \& Williams, 2001). That palatable food alone and in the absence of deprivation can powerfully increase weight gain and obesity was demonstrated four decades ago with the cafeteria-diet experiment by Sclafani and Springer (1976, Figure 6).

Just by making highly palatable fatty and sweet food items available in addition to the less palatable standard diet, the authors observed sustained increase in weight gain and adiposity of laboratory rats. It is certain that some of human overeating is a consequence of easy and convenient availability of fast foods commercially designed for high palatability. 

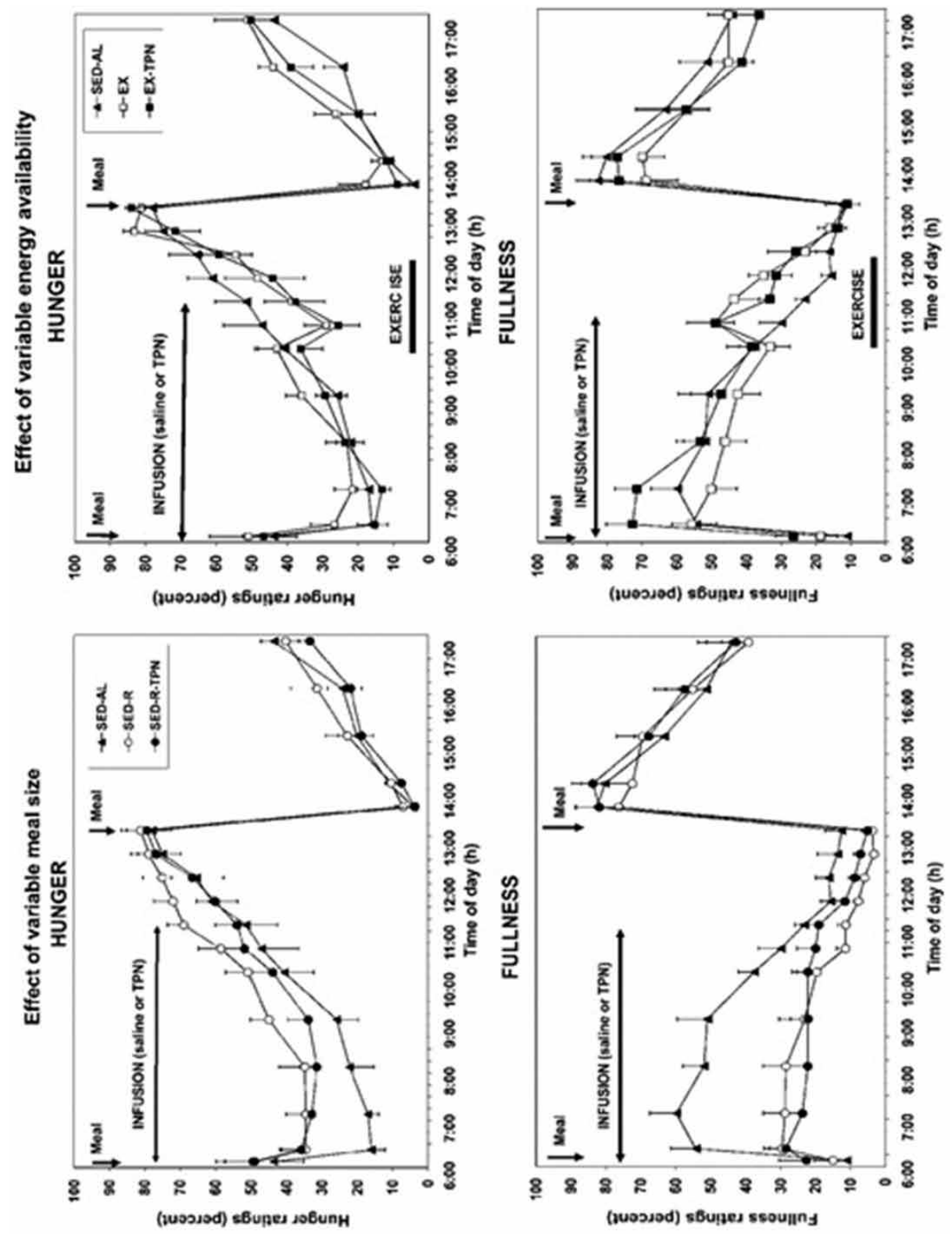

Figure 4. Hunger (top left) and fullness (bottom left) are affected only by variable-size meals that transit through the mouth and gastrointestinal tract $(2,090 \mathrm{KJ}$ meals $=S E D$ $A L, 418 \mathrm{KJ}$ meals $=S E D-R$ ) but not by $1521 \mathrm{KJ}$ of parenteral nutrition (SED-R-TPN) infused intravenously or by 2 hours of mid-morning moderate-intensity exercise expending 2315KJ (top and bottom, right). From Borer, Wuorinen, Ku, \& Burant, 2009. 

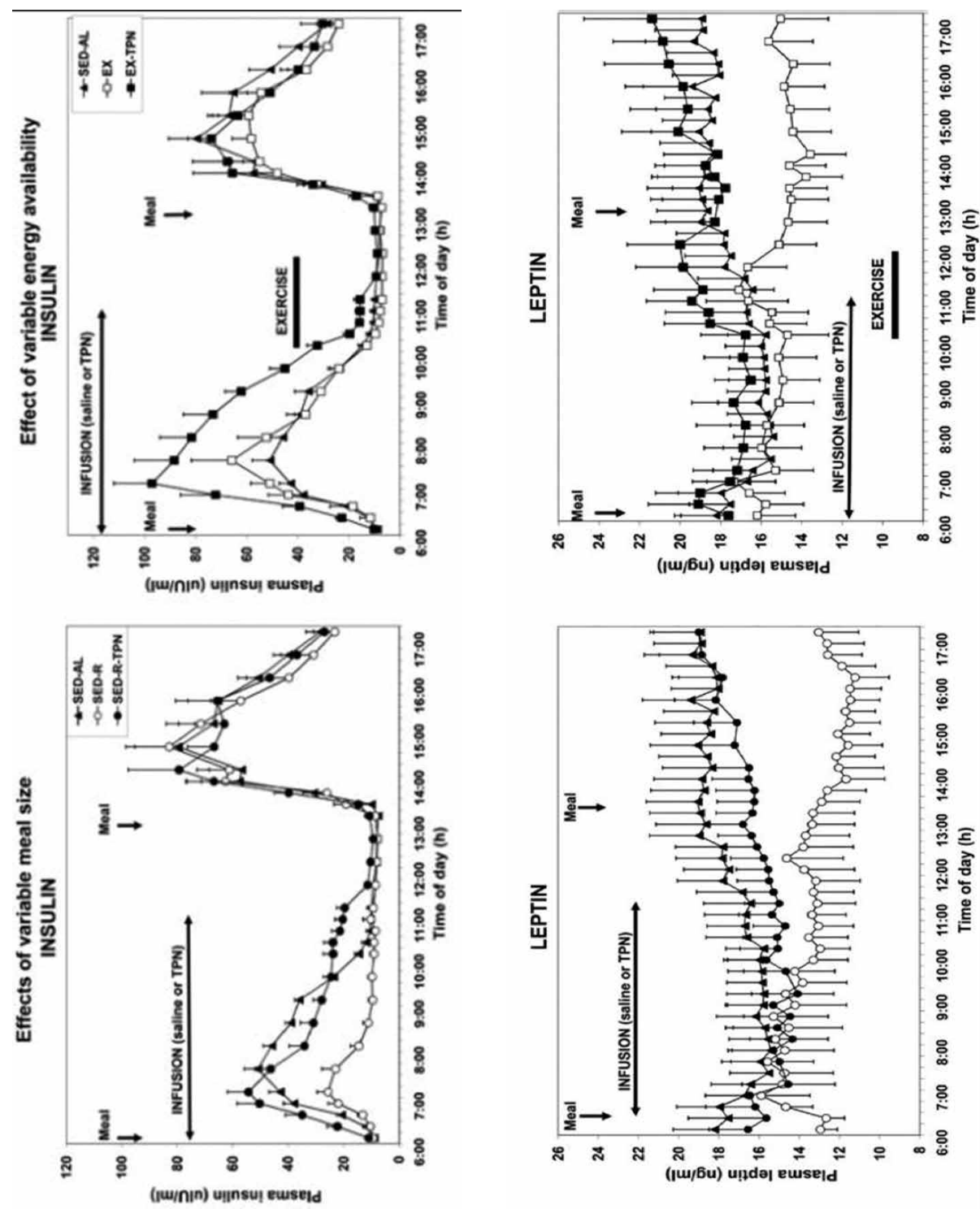

Figure 5. Accurate quantitative responses of circulating insulin (top) and leptin (bottom) concentrations to the changes in energy as a function of variable meal size (SED$A L, S E D-R)$, intravenous infusion of total parenteral nutrition (SED-R-TPN) or energy expenditure of exercise (EX-AL, EX-TPN). From Borer, Wuorinen, Ku, \& Burant, 2009. 


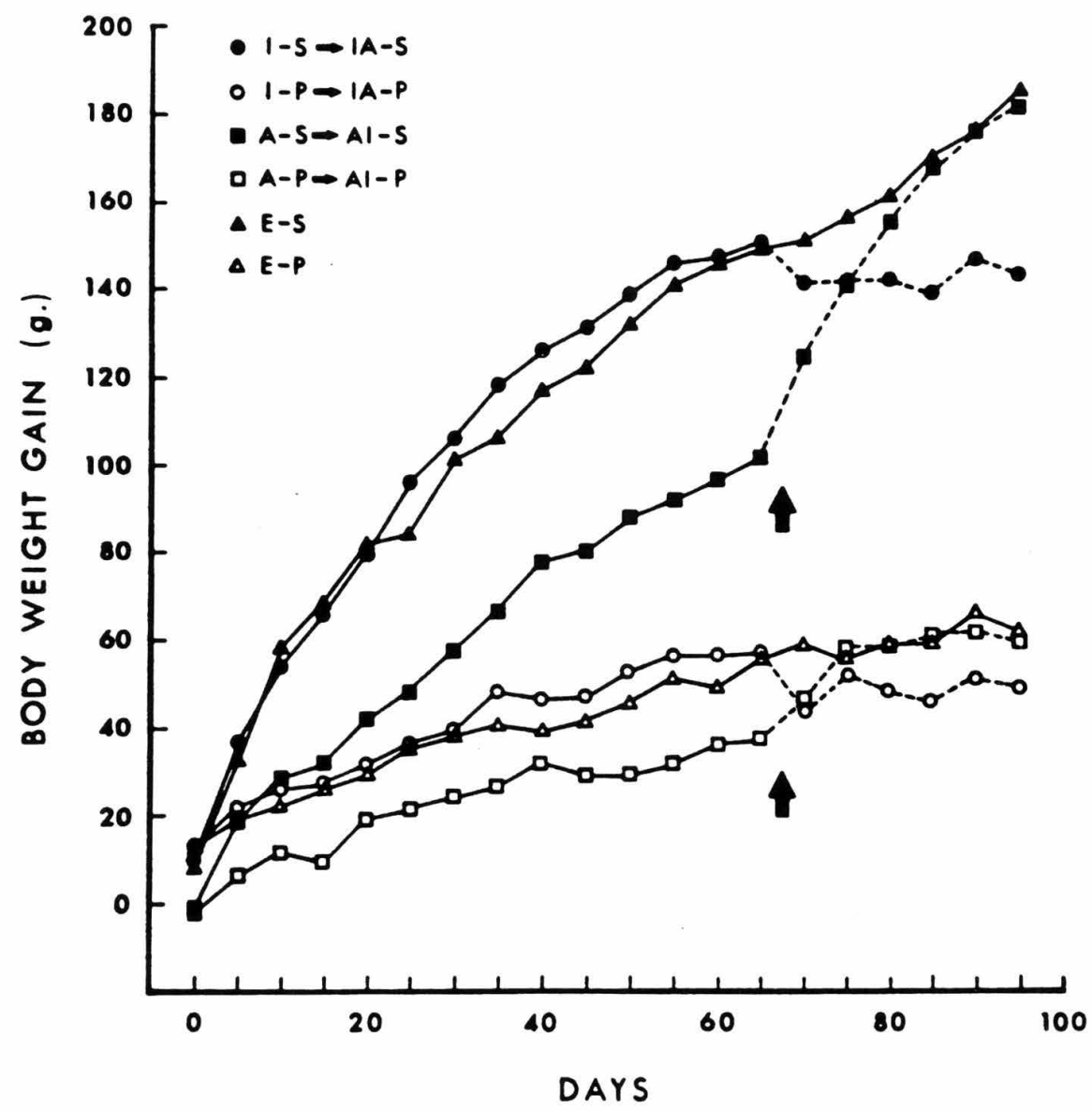

Figure 6. Cafeteria-diet phenomenon. Rapid weight gain in rats during 65 days of free access to a variety of supermarket palatable foods in addition to laboratory chow in groups I-S (solid circles) and E-S (solid triangles), compared to lower weight trajectories in rats given lab chow (groups I-P, open circle, A-P,open rectangles, and E-P, open triangles). The same fast-food dietary access with activity wheel present led to slower fat accretion during 65 days but attained the same level of obesity as E-S group after the wheel access was removed (Group A-S, solid rectangles). Introduction of activity wheels on day 65 to group E-S stopped weight gain on the fast-food diet. 


\section{Evolutionary burden of high human capacity for obesity}

Given that humans are unable to directly track calories in meals or calories expended in exercise, easy access to palatable food, and reduced opportunity for physical exertion in the modern societies lead inexorably to obesity and its metabolic pathologies. So, how did humans end up with the largest capacity to become obese among the primates (Stini, 1981)? Natural selection toward increased brain size and the capacity of the woman to bear numerous offspring may have driven the evolution of increased capacity to store body fat in humans. Evolution of larger brains in human ancestors became exponential over the past two million years (Figure 7, top) and resulted in about three-fold greater brain mass compared to that in higher primates (Ruff, Trinkaus \& Holliday, 1997, Figure 7, bottom.).

As human brain consumes between 20 and $25 \%$ of resting energy metabolism, natural selection toward bigger brains required larger energy stores. Non-arboreal existence in human ancestors has favored the evolution of unusually large brains and fat depots but not in the arboreal primates (Heldstab, van Schaik, \& Isler, 2016). Similarly, the natural selection for increased fat storage capacity has provided human ancestral females with the advantage of being able to support the energy cost of pregnancy (about $18,828 \mathrm{KJ} /$ day) and, with about 1,255 to $1,674 \mathrm{KJ} /$ day, to feed additional children. It is therefore useful to be mindful of our large capacity for fat storage and of the fact that natural selection does not operate on post-reproductive portion of the life span when most metabolic pathologies develop.

\section{Failure of spontaneous physical activity to compensate for obesity}

Voluntary physical activity declines in both humans (Rising et al., 1994; Schulz \& Schoeller, 1994, Figure 8) and animals as the body fat mass increases. This indicates that behavioral energy expenditure does not serve as a component of energy regulatory feedback to maintain stable healthy body weight. Instead of increasing as the body fat rises, spontaneous physical activity is non-homeostatic in that, the fatter the humans and animals become, the less motivated they are to be physically active (Borer, 2010).

The decline in voluntary running in experimental obesity is due to reduced motivation rather than a physical difficulty to move a larger body mass. In support of this conclusion are data showing no performance deficit in obese animals if running is enforced with a negative reinforcement (Borer, Potter \& Fileccia, 1983, Figure 9). Similarly, obese humans seeking publicity and financial incentives to lose weight in the televised "The Biggest Looser" program, clearly demonstrate that increased motivation can produce large increases in physical activity and decreases in food consumption in obese individuals (Fothergill et al., 2016; Knuth et al., 2014) that they do not show spontaneously (as shown in Figure 8).

This unfortunate non-homeostatic design for energy intake and motivation to move (Borer, 2010) may have been the result of evolutionary pressures to take advantage of 

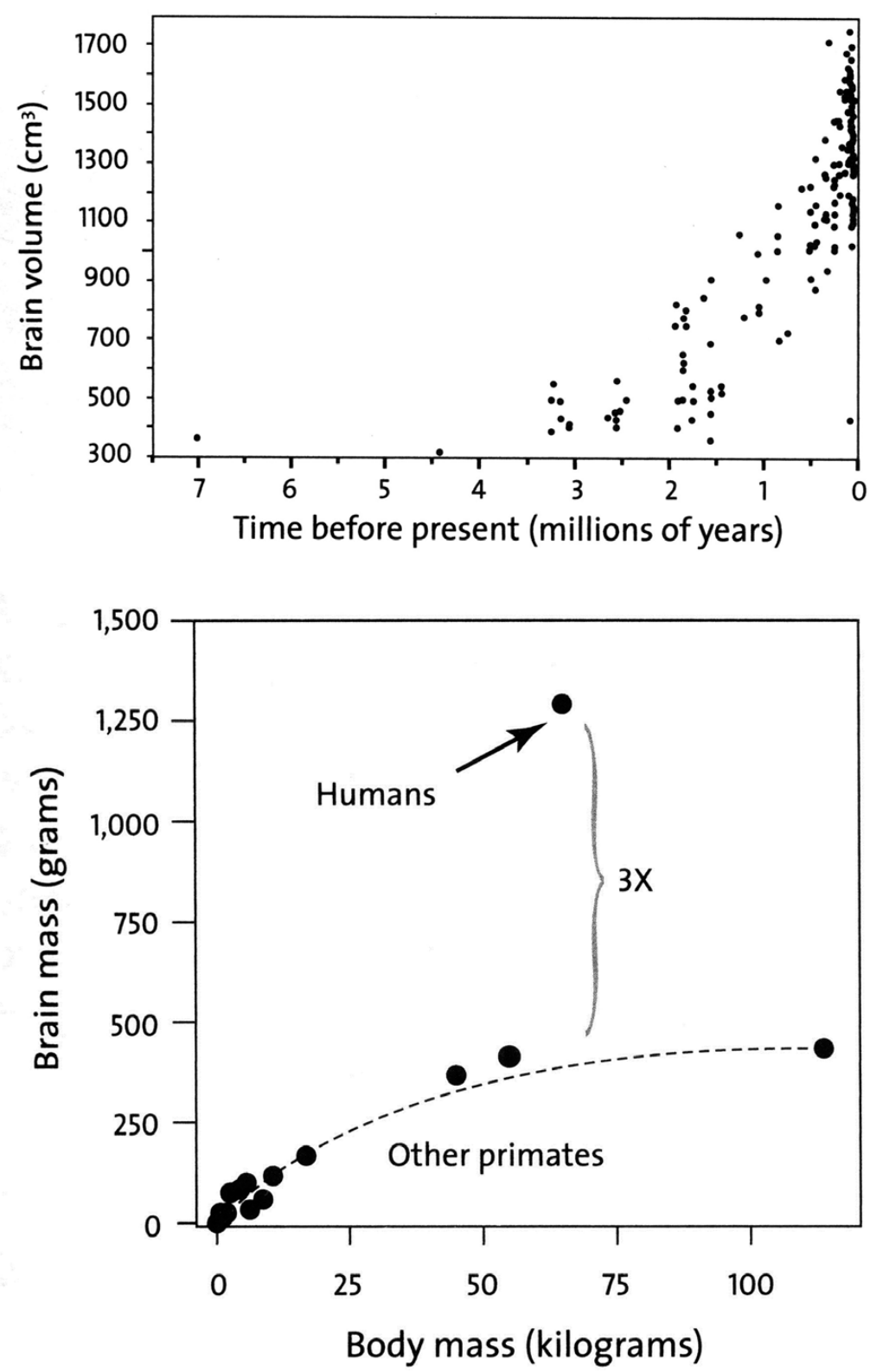

Figure 7. Exponential evolution of human brain volume during the last three millennia (top) producing about 4-fold difference between human and primate brains (bottom). Data from Ruff, Trinkaus \& Holliday, 1997, illustration from Lieberman, 2013, pages 101 and 107. 
Katarina TOMLJENOVIĆ BORER: HOW DOES EXERCISE SUPPORT DIETARY APPROACHES TO WEIGHT LOSS ..., 31-58

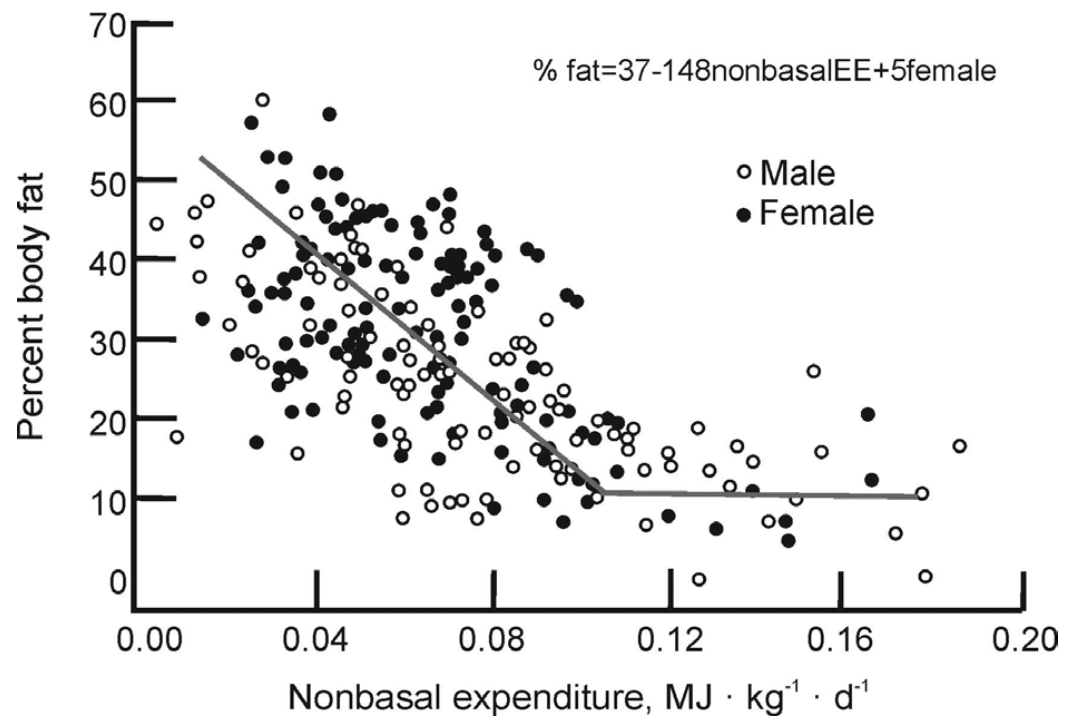

Figure 8. Inverse relationship between non-basal daily energy expenditure as a function of human percent body fat. From Rising et al., 1994 and Schulz \& Schoeller, 1994.

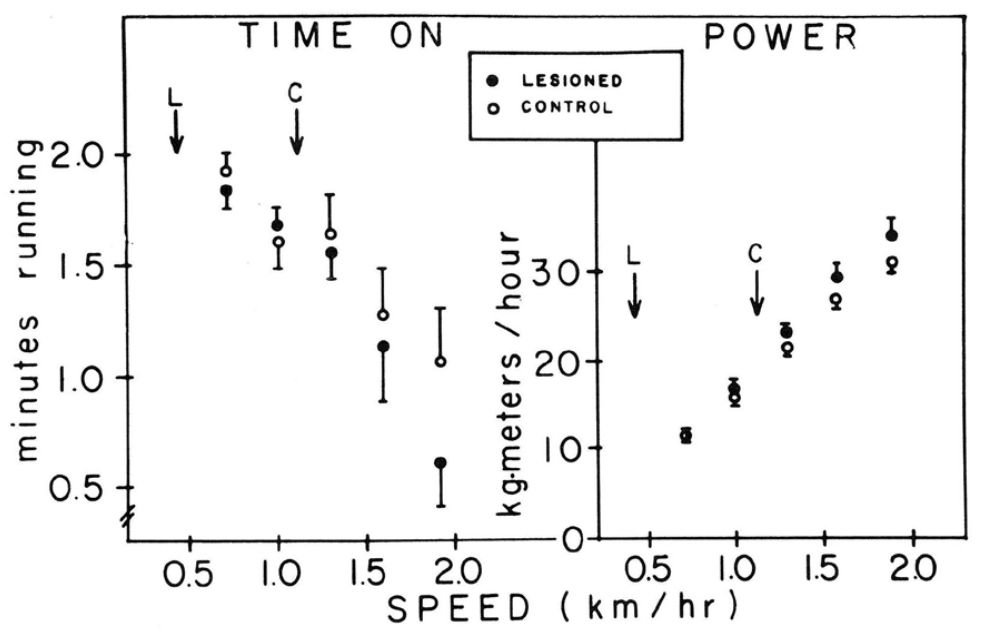

Figure 9. Obesifying septal lesions in golden hamsters (Mesocricetus auratus) produced $82 \%$ reduction in the level of spontaneous wheel running. However, when forced to run on a treadmill with electrified off-ramp grid as a negative reinforcement, obese hamsters showed no deficit in duration of running (left) or power production (right) compared to lean non-lesioned animals throughout the range of tested treadmill speeds. 
uncertain food availability in human past by increasing the search for it when the food is scarce (Chakravarthy \& Booth, 2004). Beyond the lower quantity of spontaneous physical activity with the rise in obesity, staying inactive or sedentary over several hours reduces cardiovascular health and increases risk of the morbidities associated with obesity (Després, 2016). The volumes of prescribed physical activity usually fall short of compensating for the ease with which excessive calories can be ingested and stored (Borer, 2008). Unless physical work is required for the procurement of food or some other life necessity, as was evident in Cuba during early 1990s when food embargo led to food scarcity and population weight declines (Rodríguez-Ojea, Jiménez, Berdasco \& Esquivel, 2002), human ingenuity to make voluntary physical work unnecessary is likely to persist and obesity is likely to continue to rise.

\section{Dietary and exercise solutions to some obesity-associated morbidities}

Obesity, and particularly T2D, are characterized with hyperglycemia, not only immediately after the meals, but over postprandial periods spanning substantial periods of wakefulness (van Dijk et al., 2011). Persistent hyperglycemia, as reflected in elevated hemoglobin A1c, has been associated with coronary heart disease and increased mortality (Després et al., 1996). The association of hyperglycemia and hyperinsulinemia in T2D with obesity is firmly established as both can be reduced with weight loss (Taylor, 2013). It is probable that the rapid rise in obesity and T2D in the US population since 1970's (National Diabetes Statistics Report, 2017) may have been facilitated by a $30.5 \%$ increase in daily carbohydrate consumption from $213 \mathrm{~g}$ per day in 1965 to 278 g per day or $51 \%$ of daily calories in 2011 (Cohen et al., 2015). The currently high carbohydrate consumption in the US falls within the 45 to $65 \%$ of daily calorie range recommended in 2010 by US Departments of Agriculture and Health and Human Services (Dietary Guidelines for Americans, 2010). To test the hypothesis that the postprandial hyperglycemia is largely driven by the high insulin response to a high-carbohydrate diet, carbohydrate content of the isocaloric meals was reduced in a recent study (Lin \& Borer, 2016) from $60 \%$ to $30 \%$ over a 24 -hour period.

The remarkable outcome of the study was that the postprandial insulin area under the curve was reduced by $39 \%$ by the third low-carbohydrate meal, after a 24 -hour exposure to the changed diet, but not after the high-carbohydrate meal (Figure 10). This reduced a homeostatic measure of insulin resistance by $37 \%$ (Figure 11 ).

Another insight provided by the study was that exercising for 2 hours at moderate intensity before the meals aggravated carbohydrate intolerance rather than reducing plasma glucose as exercise is expected to do (Figure 12).

The study provides helpful information that a simple dietary intervention consisting of a decrease in dietary carbohydrate and increase in healthy dietary fat and protein could restrain hyperinsulinemia that may drive fat synthesis in WAT and ectopic sites. Also, that exercise before the meals, but not after the meals (Heden et al., 2015), exacerbates postprandial glucose intolerance. 

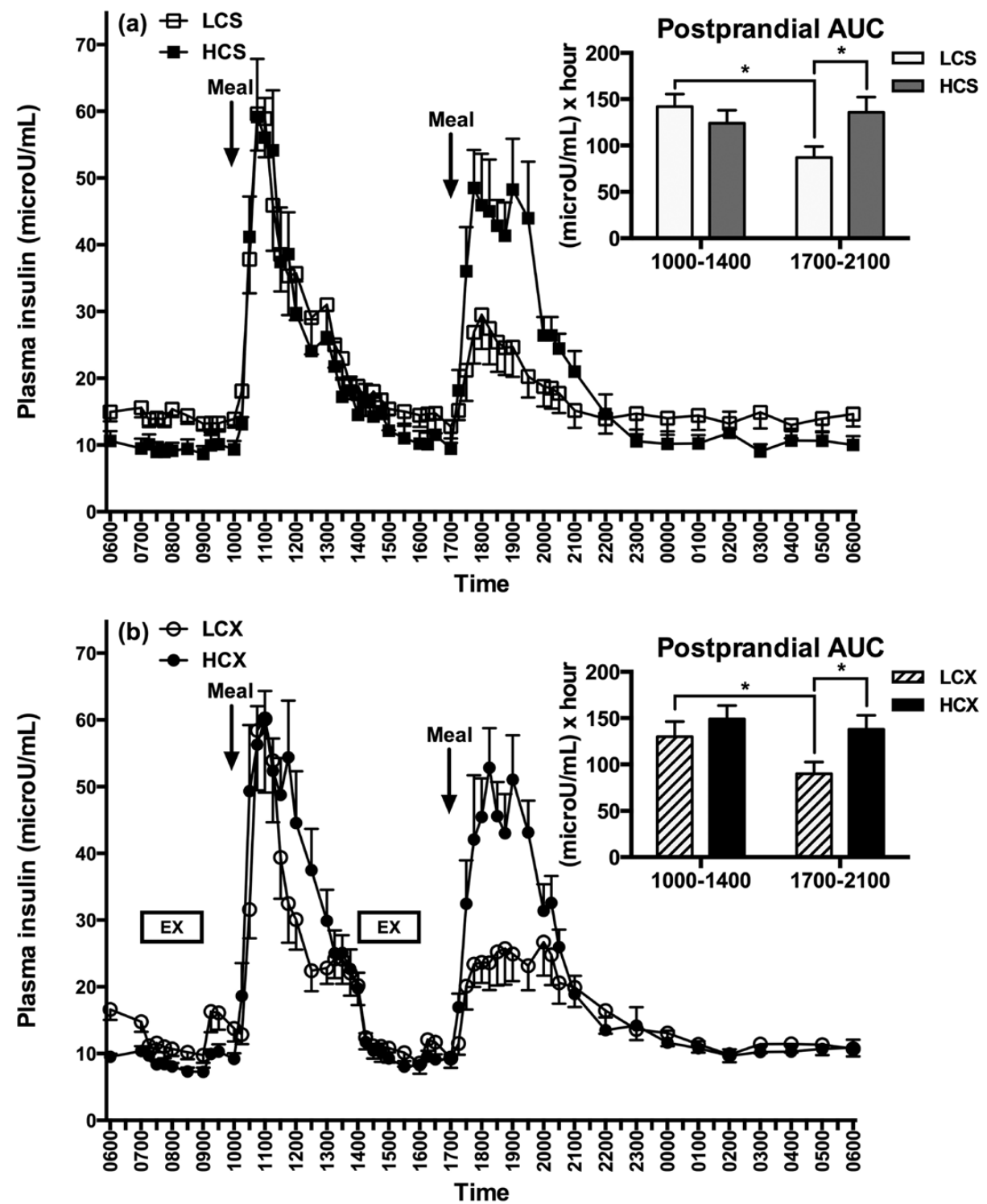

Figure 10. Reduction in postprandial insulin responses after the third low-carbohydrate meal in either (a) sedentary (LCS) or (b) exercise trials (LCX) but not in, respectively, high-carbohydrate sedentary (HCS) or exercise (HCX) trials. From Lin \& Borer, 2016. 

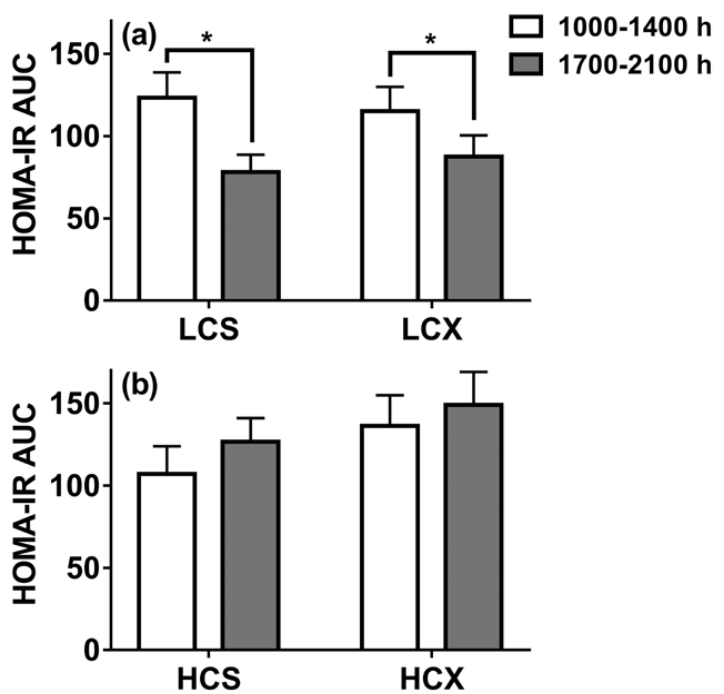

Figure 11. Reduction in HOMA-IR measure of insulin resistance after the third lowcarbohydrate meal in either (a) sedentary (LCS) or (b) exercise trials (LCX) but not in, respectively, high-carbohydrate sedentary (HCS) or exercise (HCX) trials. From Lin \& Borer, 2016.

It would be remiss not to emphasize the advantage of combining exercise with the recommended caution in selection of quantities and quality of food. This emphasis should mitigate the problems of the two already-mentioned weaknesses of physical activity in preventing or reversing obesity, its non-homeostatic nature, and its low power to overcome the ease of ingesting palatable food calories. The benefits of exercise are so impressive that since at least 2009 (Salis, 2009), the term "exercise is medicine" has been applied to the American College of Sports Medicine position stand on the benefits of exercise (Garber et al., 2011) and to the standing category of scientific presentations at the annual meeting of the American College of Sports Medicine. These sources document strong scientific evidence that regular exercise contributes to primary and secondary prevention of diabetes, hypertension, cancer (particularly breast and colon cancer), depression, osteoporosis and dementia, and while it is not very effective in weight loss, it helps maintain healthy body weight, and reduces all-cause mortality. Furthermore, it benefits human health regardless of ethnicity or age. Finally, exercise also assists weight control through temporary suppression of hunger (King, Burley \& Blundell, 1994). 


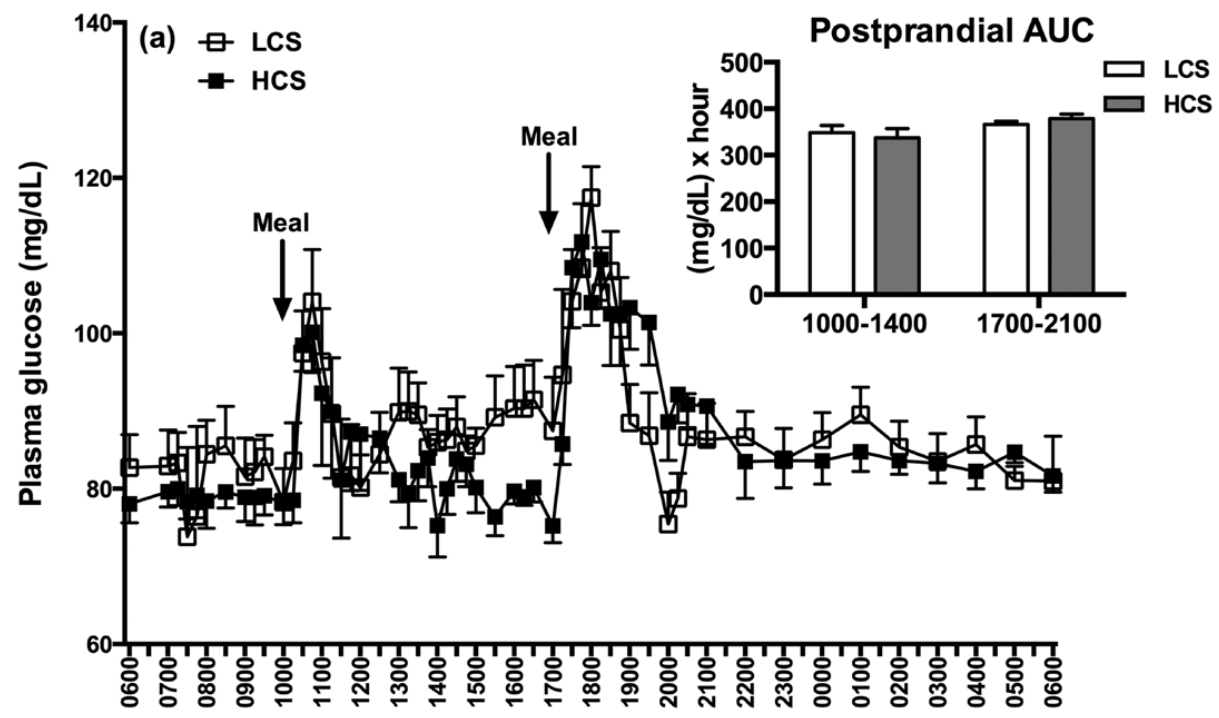

Time

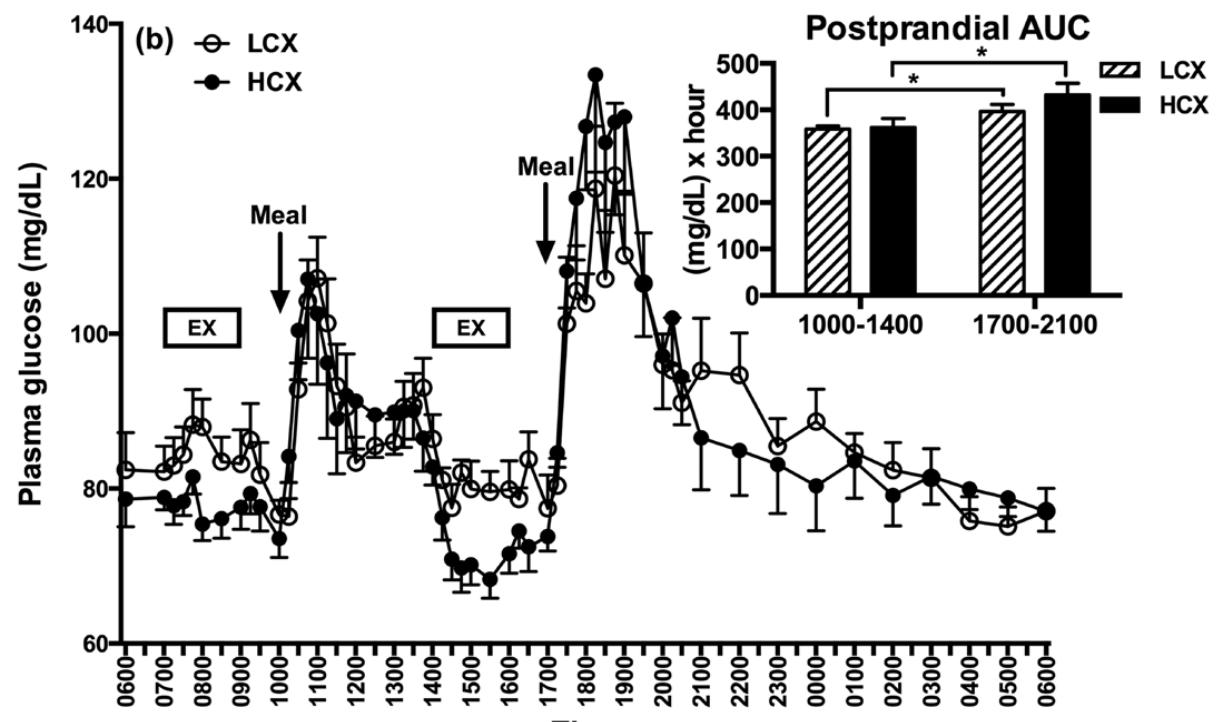

Time

Figure 12. Exacerbation of postprandial glucose intolerance in exercise trials (bottom) but not in sedentary trials (top) after the third low-carbohydrate as well as highcarbohydrate meals high-carbohydrate meals. From Lin \& Borer, 2016. 


\section{DISCUSSION}

The reviewed data were selected to help formulate some inferences, and provide guidance, regarding behavioral prevention, reversal, or mitigation of obesity and its associated morbidities. Prevention of obesity should entail the awareness that humans are unable to track calories eaten or calories expended in exercise, elaborated in the second section on The Physiological Features that Facilitate Overeating. This fact and the evidence for the powerful motivational draw to eat palatable food, discussed in the same section, should provide a cautionary note to individuals with healthy weight to exercise vigilance and restraint about quantities of food eaten and monitor and respond to their gastrointestinal signals of fullness. Preferential selection of naturally nutritious food rather than "fast food" that is commercially manipulated for maximal palatability should help counteract our innate motivation to seek palatability. Selecting a diet that is rich in healthy fats and protein and avoiding over-indulging in high-carbohydrate diet should control postprandial insulin response and the property of the high circulating concentrations of this hormone to engage in excessive energy storage. Conscious avoidance of long sedentary periods and introducing opportunities for physical work should, along with prudent eating pattern, help establish a stable and healthy body weight level.

Reversal of obesity presents a more formidable challenge. Three powerful obstacles to maintenance of weight loss include physiological defense responses to any weight reduction, be it from obese level or a healthy level. The first one is a persistent reduction in resting metabolism, the second is increased hunger, and the third is heightened efficiency of energy storage. For this reason, most of the deliberately lost weight through food restriction, with or without additional exercise, is regained in the matter or months or years (Wing et al., 2016, Figure 13).

The effect of deliberate weight loss on resting metabolic rate (RMR) was studied by Kevin Hall in individuals responding to the challenge of large weight losses seeking to win "The Biggest Loser" televised competition and compared to weight loss produced by Roux-en-Y gastric bypass surgery (Knuth et al., 2014). Both approaches produced between 40 and $49 \mathrm{~kg}$ weight loss with a smaller lean body mass loss in the television competition $(16 \%)$ than in gastric-surgery patients $(30 \%)$. However, in both groups, the reduction in RMR (characterized as the metabolic adaptation) was similarly proportional to, and associated with, a reduction in plasma leptin (Knuth et al., 2016). This metabolic adaptation in the form of reduced metabolic rate occurs in response to negative energy balance caused either by fasting or by energy expenditure of exercise. It is currently viewed as an evolutionary defense response against deviations in total daily energy expenditure (Pontzer, 2015). In this view, higher energy expenditure due to increased body mass is sustained with high energy intake, but any reduction in intake and exercise energy expenditure is compensated by a reduction in resting metabolism. This therefore means that once the increased body mass is acquired, attempts to reduce its lipid component will trigger downward adjustments in RMR. It also appears that a lack of change in gastro-intestinal scaling during weight loss does not affect the outcome, as 
voluntary-effort and gastrectomy weight losers displayed similar metabolic adaptation (Knuth et al., 2014; 2016). While this metabolic adaptation was shown to persist for up to 30 weeks post weight loss, it is not yet known whether moderate food restriction and at least 1 hour of exercise that are practiced by successful weight-loss maintainers (McGuire, Wing, Klem, Seagle, \& Hill, 1998) can, over much longer periods of time, lead to reduced total energy expenditure setpoint through proportional reductions in all components of body mass, as well as in gastrointestinal remodeling. This is suggested by a study in which an individual totally abstained from eating for 382 days and lost 125 $\mathrm{kg}$ or $60.4 \%$ of initial weight. Five years after returning to ad-libitum eating, his weight increased to only $89 \mathrm{~kg}$ from the post-fasting level of $82 \mathrm{~kg}$ (Stewart \& Fleming, 1973).

The other two variables that interfere with weight-loss maintenance and promote weight regain are a significant increase in insulin sensitivity as a result of weight loss which powerfully drives fat and glycogen re-synthesis and blocks triglyceride breakdown, and reduction of fasted plasma leptin to very low concentration (Figure 1). As most of leptin is released from the subcutaneous WAT, its role in weight-reduced state is to reduce satiation and increase hunger. This was demonstrated in powerful suppression of hunger by leptin administration to individuals who were experimentally undergoing a 10\% weight loss (Rosenbaum \& Leibel, 2014) and in persons with genetic inability to produce leptin in whom hormone administration suppressed both the hunger and reduced obesity (Farooqi \& O'Rahilly, 2014). The appetite-suppressing effects of increases in basal leptin act on the previously-mentioned brain substrates of reward (Berridge, 2009).

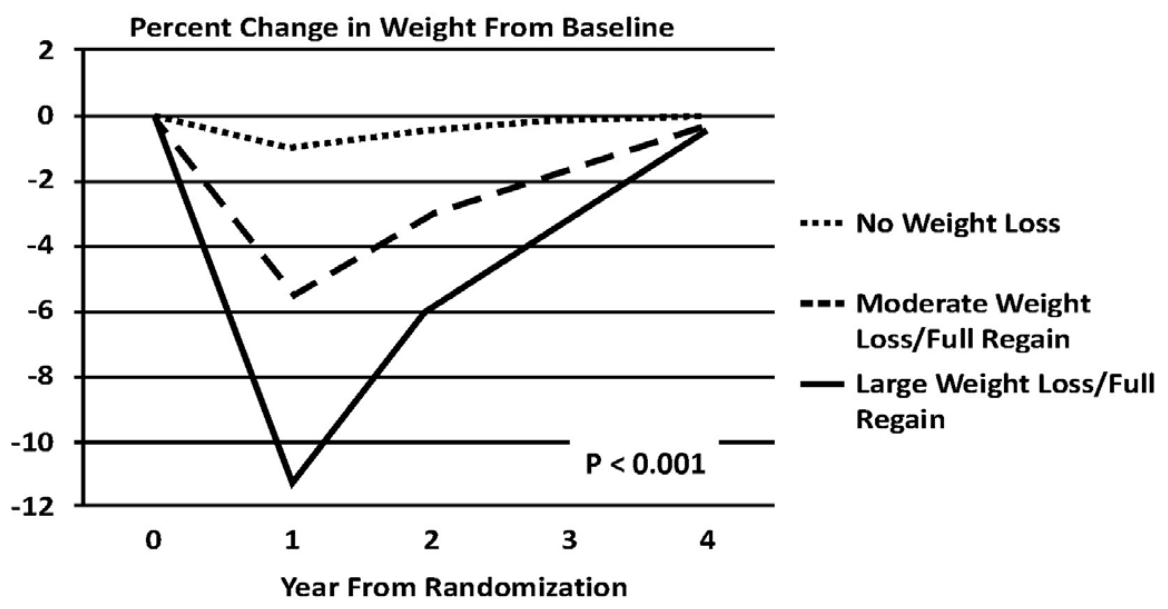

Figure 13. Patterns of weight loss and regain as percent difference from the start during 4 years of an intensive lifestyle diet-and-exercise intervention in the Look AHEAD Clinical Trial. From Wing et al., 2016. 
While there are no highly effective behavioral strategies for rapid weight loss, it is possible to sustain weight loss through deliberate control over the quantity of food eaten, daily exercise, and frequent monitoring of the weight balance (McGuire, et al., 1998). In 750 individuals tracked by the National Weight Control Registry, a $13.5-\mathrm{kg}$ weight loss was maintained for about 6 years by eating a low-calorie diet $(5,792.3 \mathrm{~kJ} / \mathrm{d}$ and $25 \%$ of daily calories from fat) and by engaging in high levels of physical activity $(11,847.3 \mathrm{~kJ} /$ week $)$.

The strategies for the mitigation of morbidities associated with obesity include reducing the carbohydrate content of the diet to lower postprandial insulinemia and glycemia (Lin \& Borer, 2016), exercising shortly after eating a meal (Heden et al, 2015) rather than before the meals (Lin \& Borer, 2016) because the former reduces postprandial glycemia while the latter exacerbates it. In addition, controlling the quantity of food eaten and changes in body weight with daily or at least weekly weighing provides helpful feedback for adjustments in energy balance, and engaging in about an hour of moderate daily physical activity contributes to a negative energy balance. Increased exercise energy expenditure and negative energy balance may, due to reduction in total metabolic rate, be responsible for the many health benefits of exercise including lower inflammatory responses leading to reduced cardiovascular disease risk, and lower stress levels contributing to endocrine and psychological health as a consequence of the reduction in non-exercise energy expenditure (Pontzer, 2015).

\section{CONCLUSIONS}

The rapid global rise of obesity incurs a heavy personal and healthcare burden due to obesity-associated morbidities and shortening of life. We explain the features of human physiology that favor fat accretion and interfere with fat loss for the benefit of individuals who use this survey of evidence on strategies for prevention, reversal, and mitigation of obesity and its sequelae. Obesifying features of human physiology include strong motivating properties of palatable food, inability to consciously detect calories eaten or expended through exercise, and hormonal and metabolic adaptations to negative energy balance that drive weight regain. We also point to the evolutionary burdens of high human capacity for fat storage and absence of a compensatory role for spontaneous physical exertion in counteracting the weight gain. Adding exercise energy expenditure to deliberate control of the quantity of food eaten will reduce the incidence of some obesity-linked risk factors that lead to cardiovascular disease despite the metabolic adaptation of reduced resting metabolism. Deleterious concomitants of obesity can also be mitigated by reducing postprandial hyperinsulinemia, namely by lowering the carbohydrate load of the diet and by exercising after, rather than before, the meals to facilitate greater glucose tolerance. 


\section{REFERENCES}

Adams, K. F., Schatzkin, A., Harris, T. B., Kipnis, V., Mouw, T., Ballard-Barbash, R., ... Leitzmann, M. F. (2006). Overweight, obesity, and mortality in a large prospective cohort of persons 50 to 71 years old. New England Journal of Medicine, 355(8), 763778. https://doi.org/10.1056/NEJMoa055643.

Bagdade, J. D. (1968). Basal insulin and obesity. Lancet, 292(7568), 630-631. https://doi. org/10.1016/S0140-6736(68)90712-5.

Berridge, K. C. (2009). 'Liking' and 'wanting' food rewards: brain substrates and roles in eating disorders. Physiolology \& Behavior, 97(5), 537-550. https://doi.org/10.1016/j. physbeh.2009.02.044.

Borer, K. T. (2005). Physical activity in the prevention and amelioration of osteoporosis in women: interaction of mechanical, hormonal and dietary factors. Sports Medicine, 35(9), 779-830. https://doi.org/10.2165/00007256-200535090-00004.

Borer, K. T. (2008). How effective is exercise in producing fat loss? Kinesiology, 40(2), 127-138. https://hrcak.srce.hr/file/48758.

Borer, K. T. (2010). Nonhomeostatic control of human appetite and physical activity in regulation of energy balance. Exercise and Sport Science Review, 38(3), 114-121. https:// doi.org/10.1097/JES.0b013e3181e3728f.

Borer, K. T. (2014). Counterregulation of insulin by leptin as key component of autonomic regulation of body weight. World Journal of Diabetes, 5(5), 606-629. https://doi. org/10.4239/wjd.v5.i5.606.

Borer, K. T. (2019). Understanding human physiological limitations and societal pressures in favor of overeating helps to avoid obesity. Nutrients, 11(2), E227. https://doi. org/10.3390/nu11020227.

Borer, K. T., Potter, C. D., \& Fileccia, N. (1983). Basis for hypoactivity that accompanies rapid weight gain in hamsters. Physiology \& Behavior, 30(3), 389-397. https://doi. org/10.1016/0031-9384(83)90142-7.

Borer, K. T., Wuorinen, E., Chao, C., \& Burant, C. (2005). Exercise energy expenditure is not consciously detected due to oro-gastric, not metabolic, basis of hunger sensation. Appetite, 45(2), 177-181. https://doi.org/10.1016/j.appet.2005.01.012.

Borer, K. T, Wuorinen E., Ku K., \& Burant, C. (2009). Appetite responds to changes in meal content, whereas ghrelin, leptin, and insulin track changes in energy availability. Journal of Clinical Endocrinology and Metabolism, 94(7), 2290-2298. https://doi. org/10.1210/jc.2008-2495.

Chakravarthy, M. V., \& Booth, F. W. (2004). Eating, exercise, and "thrifty" genotypes: connecting the dots toward an evolutionary understanding of modern chronic diseases. Journal of Applied Physiology, 96(1), 3-10. https://doi.org/10.1152/japplphysiol.00757.2003.

Cohen, E., Cragg, M., deFonseka, J., Hite, A., Rosenberg, M., \& Zhou, B. (2015). Statistical review of US macronutrient consumption data, 1965-2011: Americans have been following dietary guidelines, coincident with the rise in obesity. Nutrition, 31(5), 727-732. https://doi.org/10.1016/j.nut.2015.02.007.

Considine, R. V., Sinha, M. K., Heiman, M. L., Kriauciunas, A., Stephens, T. W., Nyce, M. R., ... Caro, J. F. (1996). Serum immunoreactive-leptin concentrations in normal- 
weight and obese humans. New England Journal of Medicine, 334(5), 292-295. https:// doi.org/10.1056/NEJM199602013340503.

Després, J. P., Lamarche, B., Mauriège, P., Cantin, B., Dagenais, G. R., Moorjani, S., \& Lupien, P.-J. (1996). Hyperinsulinemia as an independent risk factor for ischemic heart disease. New England Journal of Medicine, 334(15), 952-958. https://doi.org/10.1056/ NEJM199604113341504.

Després, J.-P. (2016). Physical activity, sedentary behaviours, and cardiovascular health: When will cardiorespiratory fitness become a vital sign? Canadian Journal of Cardiology, 32(4), 505-513. https://doi.org/10.1016/j.cjca.2015.12.006.

Dietary Guidelines for Americans, (2010). US Department of Agriculture and US Department of Health and Human Services. $7^{\text {th }}$ Edition. Washington, DC: U.S. Government Printing Office; 2010.

Farag, Y. M. \& Gaballa, M. R. (2011). Diabesity: an overview of a rising epidemic. Nephrology, Dialysis, Transplantation, 26(1), 28-35. https://doi.org/10.1093/ndt/gfq576.

Farooqi, I. S. \& O'Rahilly, S. (2014). 20 years of leptin: human disorders of leptin action. Journal of Endocrinology, 223(1), T63-70. https://doi.org/10.1530/JOE-14-0480.

Field, A. E., Coakley, E. H., Must, A., Spadano, J. L., Laird, N., Dietz, W. H., ... Colditz, G. A. (2001). Impact of overweight on the risk of developing common chronic diseases during a 10-year period. Archives of Internal Medicine, 161(13), 1581-1586. https://doi. org/10.1001/archinte.161.13.1581.

Finkelstein, E. A., Trogdon, J. G., Cohen, J. W., \& Dietz, W. (2009). Annual medical spending attributable to obesity: payer-and service-specific estimates. Health Affairs (Millwood), 28(5), W822-W831. https://doi.org/10.1377/hlthaff.28.5.w822.

Fothergill, E., Guo, J., Howard, L., Kerns, J. C., Knuth, N. D., Brychta, R., ... Hall, K. D. (2016). Persistent metabolic adaptation 6 years after "The Biggest Loser" competition. Obesity, 24(8), 1612-1619. https://doi.org/10.1002/oby.21538.

Fox, C. S., Pencina, M. J., Meigs, J. B., Vasan, R. S., Levitzky, Y. S., \& D'Agostino, R. B. Sr. (2006). Trends in the incidence of type 2 diabetes mellitus from the 1970 s to the 1990s: the Framingham Heart Study. Circulation, 113(25), 2914-2918. https://doi. org/10.1161/CIRCULATIONAHA.106.613828.

Garber, C. E., Blissmer, B., Deschenes, M. R., Franklin, B. A., Lamonte, M. J., Lee, I. M., ... Swain, D. P. (2011). Quantity and quality of exercise for developing and maintaining cardiorespiratory, musculoskeletal, and neuromotor fitness in apparently healthy adults: guidance for prescribing exercise. American College of Sports Medicine position stand. Medicine \& Science in Sports \& Exercise. 43(7), 1334-1359 https://doi. org/10.1249/MSS.0b013e318213fefb.

Guebre-Egziabher, F., Alix, P. M., Koppe, L., Pelletier, C. C., Kalbacher, E., Fouque, D., Soulage, C. O. (2013). Ectopic lipid accumulation: A potential cause for metabolic disturbances and a contributor to the alteration of kidney function. Biochimie, 95(11), 1971-1979. https://doi.org/10.1016/j.biochi.2013.07.017.

Hales, C. M., Carrol, M. D., Fryar, C. D., \& Ogden, C. L. (2017). Prevalence of obesity among adults and youth: United States, 2015-2016. NCHS Data Brief, 288, 1-8. Retrieved from https://stacks.cdc.gov/view/cdc/49223.

Heden, T. D., Winn, N. C., Mari, A., Booth, F. W., Rector, R. S., Thyfault, J. P., Kanaley, J. A., (2015). Postdinner resistance exercise improves postprandial risk factors more effectively than predinner resistance exercise in patients with type 2 diabetes. Journal of Applied Physiology, 118(5), 624-634. https://doi.org/10.1152/japplphysiol.00917.2014. 
Heldstab, S. A., van Schaik, C. P., \& Isler, K. (2016). Being fat and smart: A comparative analysis of the fat-brain trade-off in mammals. Journal of Human Evolution, 100, 25-34. https://doi.org/10.1016/j.jhevol.2016.09.001.

Iantorno, M., Campia, U., Di Daniele, N., Nistico, S., Forleo, G. B., Cardillo, C., \& Tesauro, M. (2014). Obesity, inflammation and endothelial dysfunction. Journal of Biological Regulators and Homeostatic Agents, 28(2), 169-176. PMID:25001649.

Kendall, A., Levitsky, D. A., Strupp, B. J., \& Lissner, L. (1991). Weight loss on a low-fat diet: consequence of the imprecision of the control of food intake in humans. American Journal of Clinical Nutrition, 53(5), 1124-1129. https://doi.org/10.1093/ajen/53.5.1124.

King, N. A., Burley, V. J., \& Blundell, J. E. (1994). Exercise-induced suppression of appetite: Effects on food intake and implications for energy balance. European Journal of Clinical Nutrition 48, 715-724. PMID: 7835326.

Kirkham, T. C., \& Williams, C. M. (2001). Synergistic efects of opioid and cannabinoid antagonists on food intake. Psychopharmacology (Berlin), 153(2), 267-270. https://doi. org/10.1007/s002130000596.

Knuth, N. D., Johannsen, D. L., Tamboli, R. A., Marks-Shulman, P. A., Huizenga, R., Chen, K. Y., ... Hall, K. D. (2014). Metabolic adaptation following massive weight loss is related to the degree of energy imbalance and changes in circulating leptin. Obesity (Silver Spring), 22(12), 2563-2569. https://doi.org/10.1002/oby.20900.

Knuth, N. D, Johannsen, D. L., Tamboli, R. A., Marks-Shulman, P. A., Huizenga, R., Chen, K. Y., ... Hall, K. D. (2016). Erratum: Metabolic adaptation following massive weight loss is related to the degree of energy imbalance and changes in circulating leptin. Obesity (Silver Spring), 24(10), 2248. https://doi.org/10.1002/oby.21634.

Lieberman, D. E. (2013). The story of the human body. Pantheon Books, New York.

Lin, P. J. \& Borer, K. T. (2016). Third exposure to a reduced carbohydrate meal lowers evening postprandial insulin and GIP responses and HOMA-IR estimate of insulin resistance. PLoS One, 11(10), e0165378. https://doi.org/10.1371/journal.pone.0165378.

Lorenzo, C., Wagenknecht, L. E., Rewers, M. J., Karter, A. J., Bergman, R. N., Hanley, A. J., Haffner, S. M. (2010). Disposition index, glucose effectiveness, and conversion to type 2 diabetes: The Insulin Resistance Atherosclerosis Study (IRAS). Diabetes Care, 33(9), 2098-2103. https://doi.org/10.2337/dc10-0165.

Lovren, F., Teoh, H., \& Verma, S. (2015). Obesity and atherosclerosis: mechanistic insights. Canadian Journal of Cardiology, 31(2), 177-183. https://doi.org/10.1016/j. cjca.2014.11.031.

McGuire, M. T., Wing, R. R., Klem, M. L., Seagle, H. M., Hill, J. O. (1998). Longterm maintenance of weight loss: do people who lose weight through various weight loss methods use different behaviors to maintain their weight? International Journal of Obesity and Related Metabolic Disorders, 22(6), 572-577. https://doi.org/10.1038/ sj.ijo.0800627.

Mendelson, C. R. (1996). Mechanisms of hormone action. In: Textbook of Endocrine Physiology, $3^{\text {rd }}$ ed., New York: Oxford University Press, pp 29-65.

Muller-Riemenschneider, F., Reinhold, T., Berghofer, A., \& Willich, S. N. (2008). Health-economic burden of obesity in Europe. European Journal of Epidemiology, 23, 499-509. https://doi.org/10.1007/s10654-008-9239-1.

NCD Risk Factor Collaboration (NCD-RisC) (2017). Worldwide trends in body-mass index, underweight, overweight, and obesity from 1975 to 2016: a pooled analysis of 2416 
population-based measurement studies in 128.9 million children, adolescents, and adults. Lancet, 390(10113), 2627-2642. https://doi.org/10.1016/S0140-6736(17)32129-3.

National Diabetes Statistics Report (2017). Centers for Disease Control and Prevention, US Department of Health and Human Services. Retrieved from https://www.cdc.gov/ diabetes/data/statistics/statistics-report.html.

Neuman, M. G., French, S. W., French, B. A., Seitz, H. K., Cohen, L. B., Mueller, S., ... Malnick, S. (2014). Alcoholic and non-alcoholic steatohepatitis. Experimental and Molecular Patholology, 97(3), 492-510. https://doi.org/10.1016/j.yexmp.2014.09.005.

Nowotny, K., Jung, T., Höhn, A., Weber, D., \& Grune, T. (2015). Advanced glycation end products and oxidative stress in type 2 diabetes mellitus. Biomolecules, 5(1), 194-222. https://doi.org/10.3390/biom5010194.

Olefsky, J. M., \& Reaven, G. M. (1975). Effects of age and obesity on insulin binding to isolated adipocytes. Endocrinology, 96(6), 1486-1498. https://doi.org/10.1210/endo-966-1486.

Pontzer, H. (2015). Constrained total energy expenditure and the evolutionary biology of energy balance. Exercise and Sport Sciences Reviews, 43(3), 110-106. https://doi. org/10.1249/JES.0000000000000048.

Rankinen, T., Sarzynski, M. A., Ghosh, S., \& Bouchard, C. (2015). Are there genetic paths common to obesity, cardiovascular disease outcomes, and cardiovascular risk factors? Circulation Research, 116(5), 909-922. https://doi.org/10.1161/CIRCRESAHA.116.302888.

Rising, R., Harper, I. T., Fontvielle, A. M., Ferraro, R. T., Spraul, M., \& Ravussin, E. (1994). Determinants of total daily energy expenditure: variability in physical activity American Journal of Clinical Nutrition, 59(4), 800-804. https://doi.org/10.1093/ ajen/59.4.800.

Ritz, E., Rychlik, I., Locatelli, F., \& Halimi, S. (1999). End-stage renal failure in type 2 diabetes: a medical catastrophe of worldwide dimensions, American Journal of Kidney Disease, 34(5), 795-808. https://doi.org/10.1016/S0272-6386(99)70035-1.

Rodríguez-Ojea, A., Jiménez, S., Berdasco, A., Esquivel, M. (2002). The nutrition transition in Cuba in the nineties: an overview. Public health Nutrition, 5(1A), 129-133. https://doi.org/10.1079/PHN2001284.

Rosenbaum, M., \& Leibel, R. L. (2014). 20 years of leptin: role of leptin in energy homeostasis in humans. Journal of Endocrinology, 223(1), T83-T96. https://doi.org/10.1530/ JOE-14-0358.

Ruff, C. B., Trinkaus, E., \& Holliday, T. W. (1997). Body mass and encephalization in Pleistocene Homo. Nature, 387(6629), 173-176. https://doi.org/10.1038/387173a0.

Sallis, R. E. (2009). Exercise is medicine and physicians need to prescribe it! British Journal of Sports Medicine, 43(1), 3-4. https://doi.org/10.1136/bjsm.2008.054825.

Samad, F. \& Ruf, W. (2013). Inflammation, obesity, and thrombosis. Blood, 122, 34153422. https://doi.org/10.1182/blood-2013-05-427708.

Samuel, V. T., Petersen, K. F., \& Shulman, G. I. (2010). Lipid-induced insulin resistance: Unravelling the mechanism. Lancet, 375(9733), 2267-2277. https://doi.org/10.1016/ S0140-6736(10)60408-4.

Schenk, S., \& Horowitz, J. F. (2007). Acute exercise increases triglyceride synthesis in skeletal muscle and prevents fatty acid-induced insulin resistance. Journal of Clinical Investigation, 117(6), 1690-1698. https://doi.org/10.1172/JCI30566. 
Schulz, L. O. \& Schoeller, D. A. (1994). A compilation of total daily energy expenditures and body weights in healthy adults. American Journal of Clinical Nutrition, 60(5), 676681. https://doi.org/10.1093/ajcn/60.5.676.

Schwartz, M. W., Woods, S. C., Porte, D., Seeley, R. J., Baskin, D. G. (2000). Central nervous system control of food intake. Nature, 404, 661-671. https://doi. org/10.1038/35007534.

Sclafani, A. \& Springer, D. (1976). Dietary obesity in adult rats: Similarities to hypothalamic and human obesity syndromes. Physiology \& Behavior, 17(3), 461-471. https:// doi.org/10.1016/0031-9384(76)90109-8.

Shulman, G. I. (2014a). Insulin resistance, dyslipidemia, and cardiometabolic disease. New England Journal of Medicine, 371(23), 1131-1141. https://doi.org/10.1056/NEJMra1011035.

Shulman, G. I. (2014b). Ectopic fat in insulin resistance, dyslipidemia, and cardiometabolic disease. New England Journal of Medicine, 371(23), 2237-2238. https://doi. org/10.1056/NEJMc1412427.

Sobhani, I., Bado, A., Vissuzaine, C., Buyse, M., Kermorgant, S., Laigneau, J. P., ... Lewin, M. J. M. (2000). Leptin secretion and leptin receptor in the human stomach. Gut, 47(2), 178-183. http://dx.doi.org/10.1136/gut.47.2.178.

Stewart, W. K., \& Fleming, L. W. (1973). Features of a successful therapeutic fast of 382 days' duration. Postgraduate Medical Journal, 49(569), 203-209. http://dx.doi. org/10.1136/pgmj.49.569.203.

Stini, W. (1981). Body composition and nutrient reserves in evolutionary perspective. World Review of Nutrition and Dietetics, 37, 55-83. https://doi.org//10.1159/000397997.

Taira, S., Shimabakuro, M., Higa, M., Yabiku, K., Kozuka C., Ueda, R., ... Masuzaki, H. (2013). Lipid deposition in various sites of the skeletal muscles and liver exhibits a positive correlation with visceral fat accumulation in middle-aged Japanese men with metabolic syndrome. Internal Medicine, 52(14), 1561-1571. https://doi.org/10.2169/internalmedicine.52.0521.

Taylor, R. (2013). Banting memorial Lecture 2012: Reversing the twin cycles of type 2 diabetes. Diabetic Medicine, 30(3), 267-275. https://doi.org/10.1111/dme.12039.

Than, N. N. \& Newsome, P. N. (2015). A concise review of non-alcoholic fatty liver disease. Atherosclerosis, 239(1), 192-202. https://doi.org/10.1016/j.atherosclerosis.2015.01.001.

van der Zijl, N. J., Goossens, G. H., Moors, C. C., van Raalte, D. H., Muskiet, M. H., Pouwels, P. J. ... Diamant, M. (2011). Ectopic fat storage in the pancreas, liver, and abdominal fat depots: impact on B-cell function in individuals with impaired glucose metabolism. Journal of Clinical Endocrinology and Metabolism, 96(2), 459-467. https:// doi.org/10.1210/jc.2010-1722.

van Dijk, J. W., Manders, R. J., Hartgens, F., Stehouwer, C. D., Praet, S. F., \& van Loon, L. J. (2011). Postprandial hyperglycemia is highly prevalent throughout the day in type 2 diabetes patients. Diabetes Research and Clinical Practice, 93(1), 31-37. https://doi.org/10.1016/j.diabres.2011.03.021.

Vaněčková, I., Maletínská, L., Behuliak, M., Nagelová, V., Zicha, J., \& Kuneš, J. (2014). Obesity-related hypertension: possible pathophysiological mechanisms. Journal of Endocrinology, 223(3), R63-R78. https://doi.org/10.1530/JOE-14-0368.

Wing, R. R., Espeland, M. A., Clark, J. M., Hazuda, H. P., Knowler, W. C., Pownall, H. J., ... Wagenknecht, L. (2016). Association of weight loss maintenance and weight regain on 4-year changes in CVD risk factors: The Action for Health in Diabetes (Look 
Katarina TOMLJENOVIĆ BORER: HOW DOES EXERCISE SUPPORT DIETARY APPROACHES TO WEIGHT LOSS ..., 31-58

AHEAD) Clinical Trial. Diabetes Care, 39(8), 1345-1355. https://doi.org/10.2337/dc160509.

Wuorinen, E. C. \& Borer, K. T. (2013). Circadian and ultradian components of hunger in human non-homeostatic meal-to-meal eating. Physiology and Behavior, 122, 8-16. https://doi.org/10.1016/j.physbeh.2013.08.001.

Yazıcı, D. \& Sezer, H. (2017). Insulin resistance, obesity and lipotoxicity. Advances in Experimental Medicine and Biology, 960, 277-304. https://doi.org/10.1007/978-3-31948382-5_12. 